\title{
Bibliography of the Livery Companies of London.
}

THE literature of the Livery Companies of the City of 1 London will, without doubt, at no very distant date, provide a serious task for some future bibliographer. The spirit of enquiry, both from without and from within, which is now so active, must lead to the publication of increasing stores of information as to the present progress and past history of these ancient guilds. At present, however, the works upon this subject form a very modest list, and it may be that some justification is necessary for bringing the matter before you in the present paper. I can only plead on behalf of my subject, the general desire which exists for information relating to the Livery Companies. These ancient and historic guilds of which London is so justly proud, are well known throughout the country for their benevolence, their liberal encouragement of technical education, and their generous hospitality. It is natural, therefore, that a widespread desire should be displayed for information concerning them.

But it is to the students of history, archæology, and genealogy, that the past record of the old London guilds most strongly appeals. Among their members kings, princes, and the best of England's nobility have considered it an honour to be enrolled; and London's most famous merchants, themselves the founders of many a noble lineage, have, without exception, down to very recent times, been members of these Companies and have actively discharged the duties of the various offices of assistant, warden, and master. The livery guilds also form an integral portion of the municipality of London, and their history is thus closely associated with that of the Corporation. It may be safely asserted that no period of the history of England, from the middle ages to the end of the seventeenth century, can be adequately investigated without a careful study of the history of the London livery companies. In view then of the constant enquiries for information concerning them which come under my notice, I propose briefly to indicate the following chief sources of information :-

I. General history of the subject.-English Guilds, edited by J. Toulmin Smith, for the Early English Text Society in 1870; and Gilds: thcir origin, constitution, objects and later history, 
1888, by Cornelius Walford, arc both valuable. $\Lambda \mathbf{n}$ interesting paper on the "Ordinances of some Secular Guilds of London from I 354 to I496," was read by Henry C. Coote, before the London and Middlesex Archæological Society, in 1871. Early notices of the Companies are contained in the Liber Albus, written by John Carpenter in 1419, and published in the Master of the Rolls' series of Chronicles; and in a series of extracts from the Corporation records, edited in 1868 , by H. T. Riley, as Memorials of London and London life in the $13^{\text {th }}$, $14^{\text {th }}$ and $15^{\text {th }}$ centuries. Much information is also to be found in the publications of the Public Records Commissioners, especially in the Calendars of State Papers, and in the two series of Procedings of the Privy Conncil, the first edited by Sir Nicholas H. Nicolas, in seven volumes, in 1834-7; and the second, of the reign of Edward VI., now appearing under the editorship of Mr. J. R. Dasent. Historical Reminiscences of the City of London and its Livery Companies, by the Rev. T. Arundell (1869), has no index, and is a compilation of little value. John Stow's Survey of London (Strypc's edition, 1754) is indispensable as an authority, especially on the locality of the Companies' halls. The annual City of London Directory contains a concise account of each Company, its charities, \&c., with lists of the liverymen and governing bodies. Two Parliamentary Commissions have published reports:Second Report of the Commissioners appointed to enquire into the Municipal Corporations (London Companies), 1837; and City of London Livery Companies' Commission, report and appendix, 5 vols., 1884 . The latter is full of valuable information, contributed for the most part by the Companies, but the historical side of the enquiry has unfortunately been almost entirely neglected. There remain the controversial works, Municipal London (chapter iii.), by J. F. B. Firth, 1876; and The City, an Enquiry, by W. Gilbert, 1877. Both of these are distinguished more by the bitterness of their attack than by the accuracy of their information. Some few pamphlets exist, including a report of the debate on $M r$. W. H. Faimes' notion on the City Companies, brought before the House of Commons May 23rd, 1876 . The annual Reports of the City and Guilds of Lo:zdon Institute show the progress of the colleges and classes established by that body for promoting technical education. The arms of the Companics are ficured in Londoin's Armory, by Richard Wallis, ${ }^{6} 6_{77}$; and on a snlaller scalc, in the City of Londo: Dirctory. Their charities are fully described in the Reports of the Charity Commissioners, 
and summarized in The Charities' Register and Digest, published by the Charity Organisation Society. Information about their Irish estates is given in (Sir) Charles Reed's Historical Narrative of the Irish Society, 1865, in Rev. G. Hill's Historical Acccunt of the Plantation of Ulster, 1877 , and in the proceedings in the case of the Skinners' Company against the Irish Society, 1835-45. A Parliamentary Committee is now sitting upon this question. Lists of members will be found (sometimes with places of abode) in the Poll-books for elections of Members of Parliament for the City, a collection of which from 1700 exists in the Guildhall Library. The subsidy rolls at the Record Office give valuable lists for early times. The pageants prepared by the guilds in honour of their members who become lord mayors, have been well described both by Nichols (in the Gentieman's Magazine, 1824-5) and Fairholt (Percy Society's publications, vols. Io and 19, 1843-5). The chief specimens of ancient plate, belonging to the companies are noticed in $A$ Catalogue of the Antiquities and Works of Art exhibited at Ironmongers' Hall, in May, 186r, and College and Corporation plate, by Wilfred J. Cripps, 1881. Of the seventy-seven Companies now existing, twelve have, from the earliest times, been distinguished from the rest by their wealth, importance, and greater municipal privileges. These are known as :-

2. The Twelve Great Companies.-It is a matter for surprise and regret that only six of these guilds have as yet prepared any permanent record of their past history. William Herbert's History of the Twelve Great Companies of London, published in two volumes in $1836-7$, is a work of much labour and research, although the accounts of the different Companies vary greatly in fulness. The introductory essay deals ably with many antiquarian features of their history, and copies and translations of their charters are appended. The Grocers printed a short account of themselves so long ago as $168 \mathrm{~g}$, written by William Ravenhill, their clerk. In 1829, appeared the first edition of Baron Heath's sumptuous history of the company, followed by a second edition in 1854 . The author has well illustrated the antiquarian side of his subject from the company's records, but the biographical notices of eminent members are meagre and the work has a very poor index. In 1883 , this company rendered a great service to the historical student by printing $F a c$. similes, with translations, of the early ordinances, minnte books and accounts, from 1345-1423, an example which it is much to be 
hoped other guilds will follow. Of the Ironmongers, an excellent account appeared in $185 \mathrm{I}$, from the pen of Mr. Joln Nicholl, and a second edition, with appendix, in 1866 . This work is a model of what such a history should be. It has been supplemented by a later account by T. C. Noble (1889), who was engaged, at the time of his death, in the preparation of a more extensive history. The Merchant Taylors have had the good fortune to find in Mr. Charles M. Clode, one of their pastmasters, an able historian, who compiled his Menorials of the Guild of Merchant Taylors in 1875 . This was followed, in I888, by the Early History, in two volumes, the second of which is exclusively devoted to lives of the many eminent members of the craft. An exhaustive index to the three volumes gives a double value to this excellent work. The Company also issued in 1889 , some fac-similes of their ancient deeds, dating from $133 \mathrm{I}$ to $153 \mathrm{I}$. It should be mentioned that a very early account was written by William Winstanley, in 1668, entitled The Honour of Merchant Taylors, and in 1831 appeared a work entitled The Free Enquirer into the rights and privileges of the Fraternity. Their ancient rivals, but present friends, the Skinners have also found a past-master, Mr. J. F. Wadmore, to act as their chronicler. A short account of the Company from his pen appeared in 1876 . The Salters have hitherto been content with a meagre account written by Thomas Gillespy, one of their members, in 1827. The history of the Vintners is represented by four papers read at a meeting of the London and Middlesex Archæological Society in $18 \% 0$, and reprinted by the Company in 1888 . The description of the muniments given by Mr. J. Gough Nichols, gives rise to the hope that the Company may one day be induced to have reproductions made of some of the earliest of these treasures. The remaining six "Grcat" Companies are the Mercers, Goldsmiths, Drapers, Fishmongers, Haberdashers, and Clothworkers. An account of the Mercers is in preparation by Mr. John Watney, the able clerk of the Company, who will doubtless be allowed a free hand in dealing with their early records, which are of matchless interest. il paper by Mr. E. W. Braybrook, on the eminent members of the Company has lately appeared. The Fishmongers reprinted in IS 44 their pageant, entitled "Chrysanaleia, the golden fishing," written by Anthony Munday in 1616 , on the inaururation of Mr. John Leman as lord mayor. $\Lambda$ second edition of this bcautifully illustrated folio work was issucd in 1859 . The 
Goldsmiths were first brought to light since Herbert's time in a short but interesting paper read by Major George Lambert before the London and Middlesex Archæological Society in 1883. Of the other four important Guilds absolutely no account has yet appeared.

3. The Minor Companies. - It must be premised that in the case of many of the Companies, there is a literature more or less extensive connected with the trade represented by the Company; to describe this is however beyond my present purpose. Of the sixty-five minor Companies, only twenty-three are the subject of any printed account. The Armourers and Brasiers, issued in 1878, an account of their guild, printed in sumptuous form, and prepared by their beadle, Timothy Morley. The book is without an index. Of the Barber-surgeons there exists a history by $T$. J. Pettigrew, 1853 ; a paper by Major George Lambert, I882; a Description of the Pictures by Mr. C. J. Shoppee, $1883 ;$ Memorials of the Craft of Surgery, by John F. South; and a history of the Company, by Mr. Sidney Young, now in the press.' An account of the Blacksmiths, by T. C. Noble, is appended to his History of the Ironmongers. The Brewers' Company's records extend from the beginning of the 15 th century, and a transcript of their earliest volume, edited by the writer of the present article, is now in preparation. A Sketch of the Early History of the Butchers, by Joseph Daw, was written in 1869 . An excellent history of the Carpenters was compiled in 1848 by the clerk, E. Basil Jupp; of this a new edition was published in 1889 . The Clockmakers alone among the City Companies have formed a library and museum illustrating their trade. These valuable collections are now deposited in the Guildhall Library, and a catalogue of the contents was issued in 1875 . An account of the Company, by S. E. Atkins. and W. H. Overall appeared in $188 \mathrm{r}$. A short account of the Coopers, entitled Historical mentoranda, charters, documents, E.c., 1396-1848 was compiled by James F. Firth in 1848. Of the Curriers, a short history was prepared by E. S. Norris in 1874. A Short History of the Worshipfal Company of Cutlers, by R. J. Cheesewright, 1882, leaves much to be desired. It contains an introduction borrowed. from Herbert, followed by extracts from Stow and other writers, and a list of the Company's possessions and charities. The texts of the charter and ordinances are, however, printed in full, but the book has no index.

1 Published in June, 1890. 
A paper by E. C. Robins, entitled "Some account of the history and antiquities of the Company of Dyers," was read before the London and Middlesex Archæological Society in 1880. The Annals of the Company of Founders, by W. M. Williams, 1867, gives a faithful account of the Company, and is well illustrated. $A$ Short Account of the Framework Knitters, was written in 1879 by H. C. Overall. A similar History of the Company of Horners, by C. H. Compton, appeared in 1882 . One of the best of the Companies' histories is that of the Leathersellers, by W. H. Black. This learned and sumptuous work was written in $187 \mathrm{I}$. The ordinances and other records of the Loriners will be found in an appendix to The Loriner, by B. Latchford, $187 \mathrm{I}$. The rules and orders of the Musicians were printed in 1790, 1799, and 1825, and an account of The Worshipful Company of Needlemakers was issued in 1876. The Painter Stainers printed $A$ Catalogue of the Pictures in Painters' Hall in 1832. Of the Paviors a brief account by the writer of this article appeared in 1889. The minute book of the Pinmakers, from 1710 to 1723 , is preserved among the MSS. of the Guildhall Library, and a book of accounts of the Pinners and Wiremakers, temp. Edward IV., is in the British Museum (Egerton MS. 1142). Of the Plumbers a history is in preparation by Mr. J. E. Price, at the instance of Past-Master Mr. George Shaw, whose treatise, Revived guild action, 1878 and $\mathrm{r} 890$, is also dedicated to that Company. The charter of the Poulters, with other kindred documents, was printed by that Company in 1872. An admirable account of the Saddlers, by their clerk, Mr.J. W. Sherwell, well illustrated and indexed, was issued in 1889 . Short accounts of the Shipwrights were written in 1876 by Col. $T$. D. Sewell and Dr. R. R. Sharpe. Of the Stationers many accounts have appeared; that by John Nichols, in his Literary Anecdotes, vol. 3 , contains valuable notices of the more celebrated members. Extracts from the Company's registers were printed by J. Payne Collier in 1848-9, and Prof. Edward Arber's grand transcript of the whole of the registers for the years 1554-1640, in four volumes, was published in 1875-7. There are also Historical Notices of the Company by J. Gough Nichols, 1861; A brief History by the present writer, 1880; and a paper on the Records by the clerk, Mr. C. R. Rivington, 1881. The Tylers and Bricklayers have printed their Book of Ordinances, 1570-1586. The History of the Origin and Progress of the Watermen, by their clerk, Mr. Henry Humpherus, volumes, 1-3, appeared in 1874-86. A short account of the 
Wheelwrights' Company was printed by Mr. James B. Scott, Clerk of the Company, in 1884 .

Most of these works are privately printed and are difficult to procure, they may, however, all be consulted at the Guildhall Library. In addition to the above, collections have been made for the histories of the following Companies: by Mr. D. J. Hile, for the Cordwainers; for the Pewterers by the late Sir John Staples; for the Turners by Mr. Brackston Baker; and by the late Sir T. J. Nelson, for the Weavers. Among the many minor guilds, whose history remains still unwritten, there are some of great antiquity but possessed of little wealth, whose records would certainly repay investigation. Of these may be mentioned the Scriveners, Musicians, Innholders, Parish Clerks, Bakers, Bowyers, and Cooks.

This very brief and imperfect sketch has been prepared as some sort of guide to the historical and general inquirer. Should my remarks, however, be fortunate in coming under the notice of the guardians of these ancient corporate bodies, they may help to assure them of the wide-spread interest that is felt in their history and associations. And if (as I trust is the case) I have the sympathy of the Library Association in the views which I have put forward, it will afford me satisfaction to have contributed, in however small a measure, to make more widely known the valuable records of the London civic guilds, and to render them more available for the purposes of historical enquiry.

Nore.-An enquiry into the manuscript sources of information must be reserved for a future occasion.

Charles Welch.

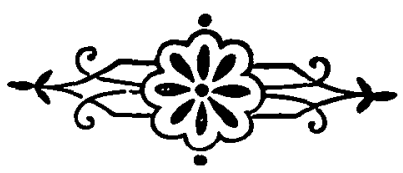

